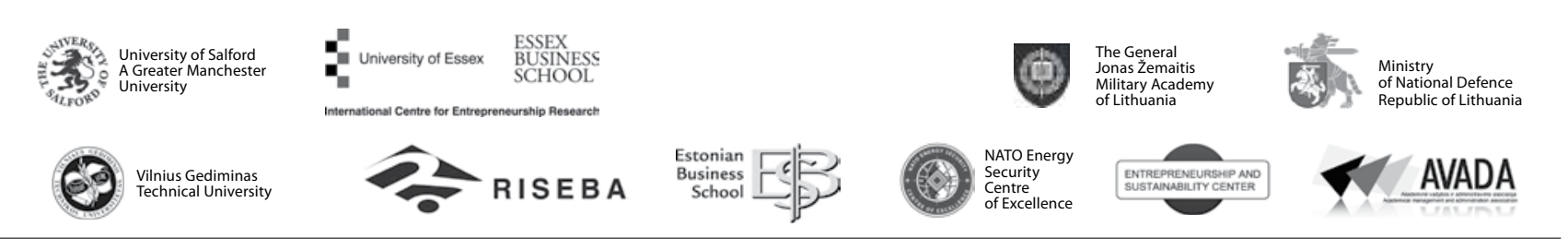

\author{
JOURNAL OF SECURITY AND SUSTAINABILITY ISSUES \\ ISSN 2029-7017 print/ISSN 2029-7025 online \\ 2018 June Volume 7 Number 4 \\ https://doi.org/10.9770/jssi.2018.7.4(11)
}

\title{
LEADERSHIP AS AN IDENTITY CREATION IN THE NEW LEADERSHIP PARADIGM
}

\author{
Danuta Diskiené $\dot{e}^{1}$ Rasa Pauliené \\ ${ }^{1,2}$ Vilnius University, Sauletekio av.9, LT-10222 Vilnius, Lithuania \\ E-mails: ${ }^{1}$ danute.diskiene@evaf.vu.lt; ${ }^{2}$ rasa.pauliene@evaf.vu.lt
}

Received 15 November 2017; accepted 20 February 2018

\begin{abstract}
New ways of communication open up new possibilities to understand groups, organizations and leaders. Leaders lead groups and organizations thus groups and organizations are reflections of their identity. The way people communicate in a group or organization reflects of how the members see themselves in the organization. Identity of each member is expressed by his or her self-perception, self-image, self-reputation, self-competences thus is not only recognized by others, but each member recognizes the others' too. As the dynamic context of reality leads to one or another type of interrelations as well as it inevitably impacts leadership practices at organization therefore research of reciprocity between leaders and other members at organizations is very important and timely. It is significant to research how people communicate to develop and maintain certain reciprocity and exactly how much, observing their interaction, could be possible to describe the environment and the people themselves. The research findings indicate that new paradigm leadership should be perceived as dynamic process resulting from interaction of people within organization and is clearly dependent on the context, and even more - on each participant identity expressed by self-competencies and on people's relations.
\end{abstract}

Keywords: identity, self-perception, self-competencies, new leadership, in-depth interview

Reference to this paper should be made as follows: Diskienè, D.; Paulienè, R. 2018. Leadership as an identity creation in the new leadership paradigm, Journal of Security and Sustainability Issues 7(4): 741-752. https://doi.org/10.9770/jssi.2018.7.4(11)

JEL Classifications: M50, M51, O15

\section{Introduction}

In recent years, numerous of studies show that leadership development is seen as increasingly important strategic imperative of an organisation, moreover, in order to survive and succeed in the present day's turbulent and highly competitive environment organisations need to develop leadership at all levels of the organisational structure. The success, survival and longevity of the organisations depend on selection of future leaders and their development; hence it is obvious that the development of the leaders capable of overcoming major difficulties is a considerable challenge for organisations of all sizes. Despite different approaches to leadership, its importance in today's world sustainability is not limited to an attempt to interpret it by integrating it into organisational management; scientific discussions lead to an even broader expression of new leadership. New ways of communication open up new possibilities to understand groups, organizations and leaders. Stacey (2003) and Covey (2004) suggest that leaders lead groups and organizations thus groups and organizations are reflections of their identity. According to Shaw (2002) the way people communicate in a group or organization reflects of how the members see themselves in the organization.

The philosopher Hegel (1807), sociologist Elias (1991) and neurobiologist Cozolino (2006) believe it is important to point out that identity is relational, i.e. resulting from one or another relationship. People in organiza- 
tions communicate trying to combine practical activities with their external environment as well as striving to self-expression, self-realization. According to Shaw (2002) thanks to these efforts people create relationships therefore it is more significant to investigate the nature of relationship arising from such situations rather than to deepen into general leadership ideas that may (or may not) emerge from such a relationship.

Problem. As the dynamic context of reality leads to one or another type of interrelations as well as it inevitably impacts leadership practices at organization therefore research of reciprocity between leaders and managers and people, i.e. colleagues, coworkers, subordinates, members of a team and other employees at organization, is very important and timely. It is significant to research how people communicate with each other to develop and maintain certain reciprocity and exactly how much, observing their interaction, could be possible to describe the environment and the people themselves. Managers' influence communications of other people at organizations thus create new forms of interaction and relationships; and the creation of new forms of interaction and relationships means an identity development too. Binney et al. (2005) offer to move away from a variety of theories as to analyze communication, relationships and reciprocity of people within the organization is more urgent and critical. Authors claim that, in this context, this is a way to find out how the leadership within organization can help and what for the phenomenon is needful.

Purpose of this article is to analyze both theoretical and research-based aspects of diversity and variety of identities within organizations as well as to present that particularity of each participant identity is expressed by his or her self-perception, self-image, self-reputation as well as self-competences thus is not only recognized by others, but each participant recognizes the others' too.

Object - leadership as an identity expressed by each participant's self-competencies notable in communication, relationships and reciprocity of people within organization.

In order to research communication, relationships and reciprocity of people within organization qualitative research method - in-depth interview - was employed. The research aims to prove that New leadership should not be perceived as something that can be acquired individually or learned but is more like dynamic process resulting from interaction and reciprocity of people within organization and is clearly dependent on the context, and even more - on each participant's identity expressed by self-competences and on people's relations.

\section{1. "The Self" concept as a key aspect in an identity creation in the New leadership paradigm}

In the New leadership paradigm a leader is seen as a person (an individual), however, it is more important that leadership as a social phenomenon manifests itself only as interaction of members of an organization and does not make sense without them. The way people communicate in either group or organization reflects of how the members see themselves in the organization thus research of the ways of communication open up new possibilities to understand groups, organizations and leaders.

In order to succeed in dynamic environment organizations are tend to place greater responsibility on leaders to develop themselves. Many authors argue that in order to take leadership the essential task for the leaders of all levels of organizational structure is to cultivate a deep understanding of themselves (Karp, 2012). Leadership is perceived not as a set of behavioral rules or distinctive character or personal traits of a leader but as a process of influencing members of organization for achieving common tasks and objectives. Therefore a leader has to take leadership and by acting this way create mutuality, reciprosity and support between members of the organization thus to constantly encourage trust and followership. Management staff influences communication of other people at organizations thus they create new forms of interaction and relationships as well as have an impact on sustainable identity formation. 
Cambridge dictionary provides with several definitions of an identity ${ }^{1}$ :

- Identity is who you are, the way you think about yourself, the way you are viewed by the world and the characteristics that define you.

- Identity is who a person is, or the qualities, or competencies of a person or group that make them different from others.

- Identity means a condition or a fact of being a specific person or thing; individuality of characteristics and qualities of a person, considered collectively and regarded as essential to that person's self-awareness.

- Identity means a condition or a fact of being the same or exactly alike; sameness; oneness, i.e. groups united by similarity of interests. 2

Speaking about capability of the New leadership, researchers prefer leadership identity, but not skills and features, as leadership identity is much broader phenomenon. Following this approach, and identifying leadership "substitute", the researchers are not about to denigrate importance of classical leadership theories. On the contrary, it is believed that formation of leadership identity is a result of hard work, in which relations with others, self-awareness and self-development processes take place. Discussions about leadership skills, traits, and styles indicate that there may be a certain constant combination of these subjects, and this may be a person who is assigned to perform a particular task or to perform certain duties. Emphasizing this, scientists today blunt the conclusions of several decades' scientists that leaders are not born, but at the same time argue that leadership is by no means a mass phenomenon, not everyone can be a leader.

Identity is a multidimensional construct used in variety spheres of social sciences to describe an individual's comprehension of him or herself as a distinct, peculiar entity (Karp, Helgø 2009). Identity in psychology is often associated with the image (i.e., the thought-based model of oneself), self-esteem, personality, and individuality. Previous researches have presented different theories of individual's identity (for example, Lecky, 1945; Mead, 1934; Wylie, 1979; Rogers, 1961; Cooley, 1902; Colby, 1968). However, the psychologist and psychoanalyst, who created one widely recognized theory Erik Erikson (1959), suggests defining the identity as a separate concept, i.e. without reference to the person's peculiarity, exclusiveness, etc., which helps to separate one person from another. Development of an identity can be overlooked in several phases in which the identity is shaped as a response to challenges and human interactions. An individual can express his or her personality in behavior or conversation (discourse) to another person. Therefore, another person's intentions may be indirectly implied by certain signs that the person sent. Personal characteristics determine personal identity, i.e. the individual's personal, subjective self-assessment as an individual subject and his or her image. This subjective understanding of self can contrast with other aspects of the personality, for example, contrast can occur between "true me" and "visible to others" or "ideal me" and "what I need to be" (Higgins, 1987).

Marcia (1966) focused on the main aspects of identity development - choice and commitment - in the 1960s. The essence of this statement is that each person's identity perception is largely determined by his or her own choices and commitments that it incurs due to certain personal and social features. $21^{\text {st }}$ century researchers also claim that many of these choices are affected by values. Some researchers argue that values create choices, and choices create values. Different situations inspire manifestations of different aspects of personality, and selfawareness, identity may change due to various external stimuli and environmental challenges (Kark, van Dijk, 2007). Social psychology focusses on interpretation of individual performance through self-imposed mental phenomena and explaines, examines how "true self" is linked with social environment. Some social psychology theories investigate the problem of identity, both at individual cognitive and collective levels of behavior (for example, Day et al, 2008). Social psychology theories state that there are certain identity-forming strategies that can be undertaken by a person who wishes to adapt to the social world (the society). Higgins (1987) argues that humans have two basic self-control systems. One of them is a pursuit of future benefits, and the other - an avoidance of punishment, therefore goal-seeking objectives reflect the "Ideal Self," and the objectives of prevention are regulated in order a person behaves as others demand.

1 https://dictionary.cambridge.org/dictionary/english/identity

2 https://dictionary.cambridge.org/dictionary/english/identity 
Looking from the perspective of leadership theory, Burns (2003) and Bass and Avolio (1994) focus their researches on relations between leaders and followers (e.g. from the very recent studies Naushad, M. 2018) As a result, researchers are increasingly analyzing psychological consensus of leaders and other members at an organization, emotional compliance, and recent researches point to the importance of dynamics of relationship between leaders and other members at the organization. Some authors (for example, Dearlove, Coomber 2005) argue that self-awareness is the basis of personality development. Others, for example, Scharmer (2007), argue that many theories of social science in the $20^{\text {th }}$ century have focused on objective social facts, structures, systems and processes in which such social constructs are formed between participants in the social system, and therefore such theories in social sciences did not succeed in this regard. According to Scharmer (2007), internal stimuli stimulate and involve the individual into interaction with other people. The activity comes from linking itself to a certain place and role in the social system, social processes. As a person constantly communicates with others, the development of a person is strongly related to interaction of people. Carl Gustav Jung (1969/1978), the pioneer of analytical psychology, states that people have an inherent need for self-realization, which is why this process is called individualization or becoming an individual. By communicating people try to create their own unique identity, Jung suggests that a goal of each person's self-realization should be considered as a desire to get closer to the highest possible constitution of his or her own identity. In this case, human identity is understood as a movement in space and time, which in mind manifests itself as a perception of human interactions and is influenced by a set of images created in the past, also present and future images. Jung's human images of the past have been described as "Grounded Self"; the present images have been identified as "True Self", and future images - as "Possible Self". Other similar descriptions are suggested by Higgins (1987), i.e. "Actual Self", "Ideal Self", "Ought Self".

\section{Aspects of an identity as a certain leadership role in the New leadership context}

The particular characteristics of "The Self" determine its identity - the individual's personal, also subjective comprehension of him or herself, i.e. his or her self-perception, self-image, self-reputation, self-competences and its' expression (Karp, Helgø 2009). Moreover, this subjective comprehension of "The Self" may contrast the other domains of "The Self"; namely between "own" versus "others" images of self-state representations, or the distinction between the "Ideal Self" and the "Ought Self" (Higgins, 1987). This raises a question: if leadership is dependent on identity, how should be leadership based on an identity?

Disclosure of an identity and emphasis on leadership requires personal development (Day et al. 2008). Leader's life stories form a context of his or her experience, i.e. not only facts of people's lives are important, but also personal life stories. The past and present and future stories and images play an important role and inspire internal reflection. People, in order to give meaning and to discover their own path, recreate many times and experience events and personal interactions that are important in their lives. Day (2001), McAdams and Pals (2006) believe that such processes are also applied to leadership development in organizations. Based on Jung's concept, the authors suggest that leadership identity should be evaluated in the light of images of the past ("Grounded Self"), of the present ("True Self") and of the future ("Possible Self"). According to this statement, researchers do not rely on linear time understanding; on the contrary, it is guided by cyclical concept of time, moreover - that the past is not a gift. The past is what, in the view of people current expectations for the future, is repeated in present. According to Stacey (2003), current expectations of the future have an impact on perception of the past, and the way people perceive the past now influences future expectations. Thus, based on personality psychology, the present ("True Self") is characterized by a cyclical structure of time that includes the past ("Grounded Self") and the future ("Possible Self"). James Kouzes and Barry Posner conclude that the mastery of the art of leadership comes with the mastery of "The Self". Researchers believe that understanding of leadership identity is defined by choices and commitments that it carries in various difficult situations, exposed to different personal and social characteristics.

Lately, scientific research on leadership and authenticity has been increasing (for example, Goffee, Jones, 2005; Dearlove, Coomber, 2005; George, Sims 2007; Pearce and Conger, 2003). Dearlove and Coomber (2005) argue that leaders, who, for various reasons, miss the necessary stages of self-awareness, can later demonstrate 
identities that do not meet their values or convictions. According to the authors, such leaders may be harmful to organizations if the organizations tolerate obvious leadership weaknesses in long-term. Researchers argue that leadership growth and progress without self-awareness are not possible (Hautala, 2006). Jung and Avolio (1999) define self-awareness as a continuous process of individualization. Many authors argue that self-awareness, self-competencies' expression and self-development yield better self-control, self-esteem and self-confidence significant factors for a leader who desires to take leadership. Kouzes, Posner (2002) believe that leadership development is a process of self-development too. However, some researchers make a theoretical distinction between leader development and leadership development (Karp 2012, Day 2001). In theory of leadership development a higher focus is placed on interpersonal capabilities, i.e. social awareness and social skills, while in theory of leader development higher attention is on intrapersonal capabilities, i.e. self-awareness, selfregulation, self-motivation and self-competencies' expression. It should be pointed out, however, in practice such capabilities need to go hand-in-hand because a leader needs to take leadership and therefore to develop himself or herself and his or her ability to interact with other people and the environment too.

Not all authors agree with the above views on effective leadership and argue that there is pre-thinking (intentionality) in leadership activity. Some authors (e.g., Badaracco, 2006) believe that for some leaders their own dreams are source of intentionality. Others argue that a leader has very important intentionality that manifests itself as a vision (Senge, 1995) or a certain strategic ambition (Alexander, 2005). The third argue that intentionality emanates from persuasive future images and expectations that manifest themselves in the form of visions, strategies, directions, etc., and this is part of leadership. Carl Gustav Jung defined this area of human identity as future images or "Possible Self"". The fourth conclude that future images that appear in intentions, expectations, dreams, visions, ambitions, or other forms are rooted in human nature and in everyday life (for example, Badaracco, 2006). The fifth authors in the concept of creation of new leadership identity argue that leadership is defined by future image and expectations of a leader. The authors call it as "The Leadership Possible Self" and suggest leaders to consider the following issues: What are their intentions, expectations, dreams, visions, ambitions, strategies and, more pragmatically speaking, how they perceive and describe the future? What is their most worrying concern about their role in society and what they can offer in a new, different way? Despite the diversity of leadership definitions, most people present intentions describe as the images they would like to achieve in the future, which is why they believe that it defines quality of the New paradigm leadership. Most leaders, in developing their own leadership identity, find motivation in the future expectations. Finding and expressing ownself in leadership creates a risk because one person's selfish "Self" is more acceptable than others'. It is also important that disclosure of individual and unique leadership styles always requires constant development of each and every leader own "Self". Reflection on identity and attempt to reconcile this with leadership is a continuous process that lasts entire career of each leader.

Over the years different theories of "The Self" have been identified in both self-psychology and self-management. To find one's authentic, ideal or true "Self" is trully a nice ideal, but its realization and implementation in practice is rather difficult. More important is to find, or define, a self-determined by oneself (Karp, 2012). Authors therefore argue that "The Self" is not a stable inner core but a stream of actions, and that the comprehension of self-change is due to various situations and both external and internal stimuli as well as interaction and reciprocity of people within organization.

\section{Research method, ethical consideration and limitations}

In this study, the researchers aim at constructing the reality of leaders and managers and people, i.e. colleagues, coworkers, subordinates, members of a team and other employees at organizations under study. They attempt to understand the reality that the members at organizations experience concerning communications, relations, interaction and reciprocity in their everyday life, based on interpretations (Sarantakos, 2013). In-depth interviewing is a qualitative research technique that involves conducting intensive interviews with a small number of respondents individually to explore their perspectives on a particular idea, program, or situation. In-depth interview instrument gives quite correct and accurate feedback of individual strengths and specific competencies. 
In order to measure particularity of identity of each participant that is recognized by others as well as to present of how each participant recognizes the others' a measurement tool in the form of a questionnaire has been designed. The research adopts a positivist and qualitative approach employing previously developed instruments to assess participants' opinions, attitudes, and beliefs concerning preferred competencies, communication and relationship behaviors as well as reciprocity of people within organization. Survey assessing both „Self“ and „Others" attitudes were administered based on pre-existing scales that have been modified for the study. Interview questionnaire was based on Competency assessment tool, namely, МCPTM (Managerial Competency Portfolio $360^{\circ}$ Assessment) (Hay Group 2013) and Leadership practices inventory (LPI) (Kouzes, Posner, 2013). In order to reach the research purpose the two core competencies' clusters - managing yourself and enable others to act - have been chosen. The questionnaire covers 21 question formed as contingency priority, i.e. 6 questions highlighting competence "managing yourself" and 15 questions highlighting competence "enable others to act" are included.

The two core competencies' clusters and the five scales (self-control, self-confidence, empathy, foster collaboration, strengthened self-determination) conceptual model is based on Leadership practices inventory (LPI) framework (Kouzes, Posner 2013):

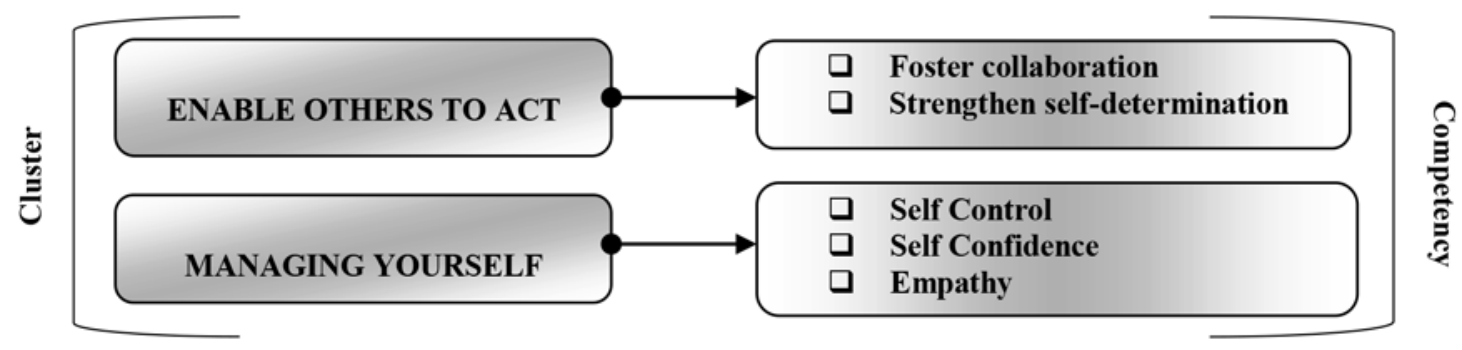

Fig. 1. Two core competencies' clusters and five competencies' scales conceptual model

Source: Adopted according to Leadership practices inventory (Kouzes, Posner 2013).

The interview was performed at two business consultancy companies operating on the Lithuanian market. The consultancy companies are classified as medium business enterprises that employ 10-50 employees. 24 respondents, 9 females and 15 males, the average age 35.6 years ranging from 26 to 59 years old participated in the in-depth interviewing. 2 top managers, 14 senior project managers, 8 managers and specialists, all respondents university master degree education, having the average 6.2 years work experience in the consultancy sector were interviewed individually. The interview was doubled, i.e. questionnaire was discussed and filled in individually by a respondent about him/herself (About Self) and by the respondent about his colleagues' (About Others).

Confidentiality and anonymity have been ensured through the data collection process and interpretation, also through both preparation and presentation of the research report. Majority of the respondents agreed and the researchers were allowed voice recording, except eight objected to it; therefore the respondents submitted their responses in writing on paper during the interview. The averall respondents' answers were analyzed through an inductive approach of content analysis. Content analysis is defined as the technique of analyzing qualitative data that can be carried out on transcribed interviews (Basit, 2010). The six steps of data analysis suggested by Lodico, Spaulding and Voegtle (2010), namely preparing and organizing the data; reviewing and exploring the data; coding data into categories; constructing thick descriptions of people, places and activities; building themes; and reporting and interpreting data were used (Jinot 2018). Answers of each respondent under the study have been combined with other respondents' responses, thus identified the highest-developed competencies and the competencies that still need to be considered, strengthened and unified.

The in-depth interview proceeds as a confidential and secure conversation between an interviewer and a respondent, however, important limitations should be pointed out. One of well-known is Halo error when a 
respondent under study is seen by others as good or bad, depending on his/her reputation rather than his/her true performance. It can also be encountered with the current impression (i.e. Recency effects) error, i.e. if the respondent has been successful only resent a few weeks, although he/she was not doing well all year round. The respondents were reluctant to participate in the interviews due to confidentiality and anonymity aspects. While performing in-depth interview was very important to inspire trust of all respondents: the assessments remain anonymous; the assessments remain confidential; the results will be used for positive purposes.

\section{Data analysis and findings}

The purpose of this paper is to present particularity of each participant's identity expressed by his or her self-perception, self-image, self-reputation and self-competences, and to examine of how each participant is recognized by others as well as how each participant recognizes the others'. Five competencies' scales (selfcontrol, self-confidence, empathy, foster collaboration, strengthened self-determination) representing two core competencies' clusters - managing yourself and enable others to act - were included to express particularity of the participants identities.

A significan gap between self-evaluations (,About Self“) and evaluations of other people at the organization they work (,About Others") was revealed (Figure 2): 
COMPETENCES:

\section{INTERVIEW QUESTIONS / STATEMENTS:}

RESPONSES:

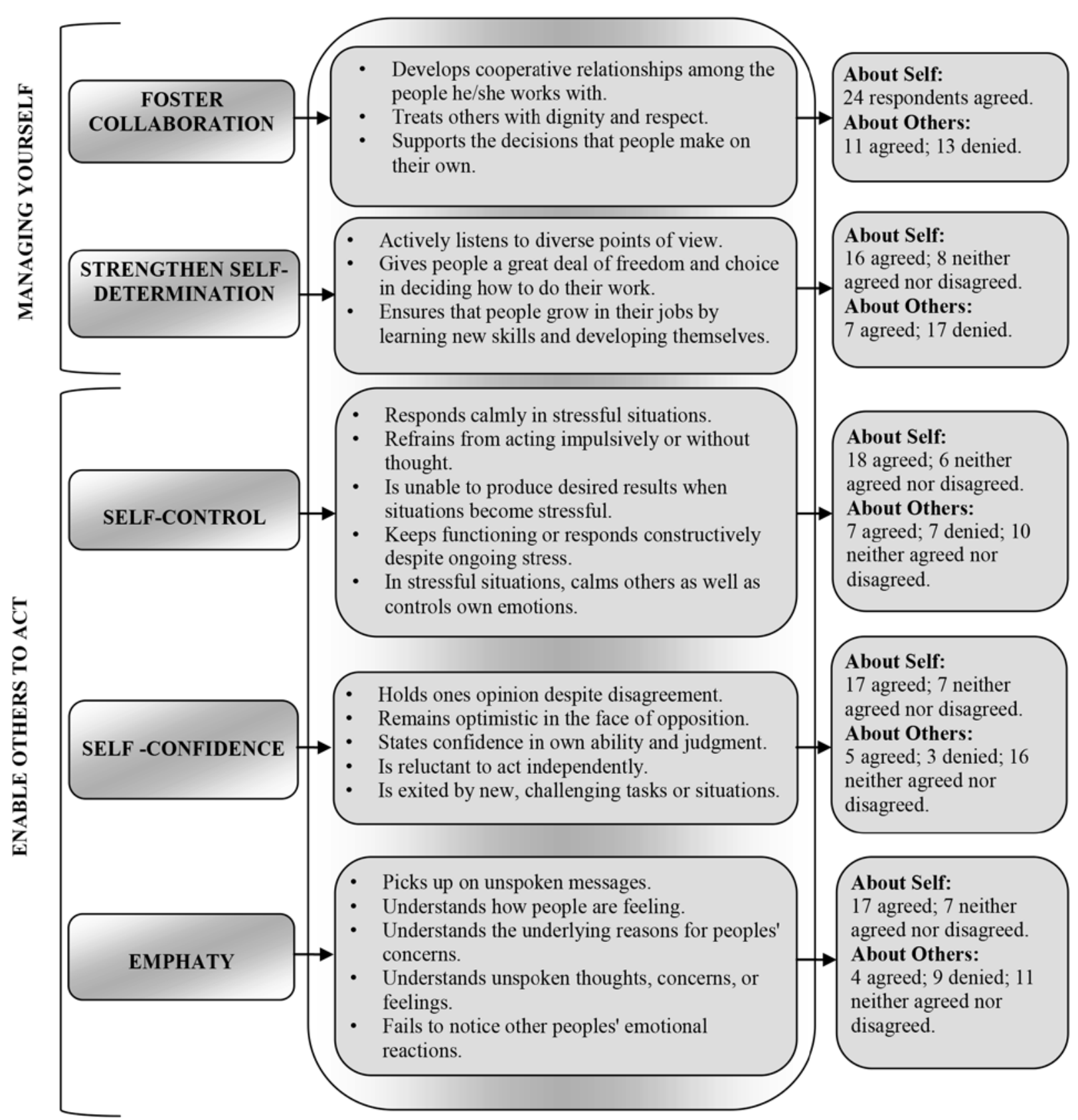

Fig. 2. Results of self-control, self-confidence, empathy, foster collaboration, strengthened self-determination evaluations „About Self“" and evaluations „About Others“"

Source: compiled by the authors based on research results

\subsection{Foster collaboration}

All 24 respondents believe that foster collaboration in both strategic issues and every day activities (,About Self"), however, evaluating other members of the organizations 11 agreed and 13 denied („About Others“). Manager from company A - female, age 37 - explained the disinterest of his colleagues: „Majority of my colleagues consider themselves as top opinion leaders and do not see any need to find out others "opinions". Manager from company B - male, age 34 - did not hesitate to elaborate: ,My colleagues never ask, never call for a piece of advice. They make mistakes suggesting discounts to clients, so this worsens annual results of our company". 


\subsection{Strengthened self determination}

16 respondents agreed, although 8 had doubts about "Self". Manager from company A - male, age 53 - stated: "I am really attentive and actively listen to diverse of points of view of my colleagues, however, I cannot be proud I always give my colleagues a great deal of freedom and choice in deciding how to do their work". On the other hand, only 7 agreed and 17 disagreed about „Others“ claiming that they are not given a great deal of freedom and choice in deciding how to do their work. Three managers from company B - female, age 42; female, age 51; male, age 32 - complained: „The authorization is not clear and I am confused sometimes about notes I hear from my colleagues: it makes me feel self-consciousness, sometimes - shame or awkwardness“".

\subsection{Self-control}

Majority of respondents (18 from 24) agreed, 6 neither agreed nor disagreed about "Self", however, 7 agreed, 7 denied and 10 neither agreed nor disagreed about other members" self-control (evaluation of „The Others"). Manager from company A - male, age 54: „Even a small disagreement brings about a conflict, which then grows into a long-lasting dispute. It is distressing; it prevents concentration on further work". Manager from company B - male, age 37: "Only very few can respond calmly in stressful situations at our company". Manager from company B - female, age 46: „I am not able to focus on work that day: I usually leave and work from home“. Manager from company B - female, age 28: „,... there are two-three peacemakers in stressful situations at our organization, they calm others and are doing great to control own emotions".

\subsection{Self confidence}

A significant gap was revealed in self-confidence evaluation: 17 agreed and 7 neither agreed nor disagreed about „Self“, however, 5 agreed; 3 denied; 16 neither agreed nor disagreed about „Others“. Majority of respondents (17 from 24) pointed out about "Self" that they hold their opinion despite any disagreement, also state confidence in their own ability and judgment, however, emphasized that have difficulties to remain positive and optimistic in the face of opposition. Significantly, majority of respondents (19 from 24) claimed about „Others“ for resisting and ignoring necessity of changes, for being too much exited by new, challenging tasks or situations.

\subsection{Empathy}

7 had doubts (i.e. neither agreed nor disagreed), although majority of respondents - 17 from 24 - agreed about „Self", pointing out that they easily pick up on unspoken messages as well as usually understand how people are feeling. However, evaluating others' only 4 (from 24) agreed; although 9 denied and 11 neither agreed nor disagreed („About Others“). Six managers from company A - female, age 29; female, age 32; male, age 44; male, age 41; female, age 51; male, age 54 - stated: „,.. my colleagues hardly ever understand unspoken thoughts, concerns, or feelings. They fail to notice other peoples'emotional reactions, so this is the main reason why conflicts begin". Eight managers from company B - male, age 51; male, age 40; female, age 28; female, age 39; male, age 42; male, age 53; male, age 54; male, age 37 - emphasized that it is critically important to understand not just own thoughts and concerns, but to perceive others' unspoken thoughts, concerns, doubts, both negative and positive emotions and feelings. 


\section{Conclusions and future research}

This study was carried out and designed to identify and present particularity of evaluations towards "The Self" and "The Others" among employees at two business consultancy services' companies. Almost all the respondents interviewed pointed out certainty and self-awareness, however, while evaluating other members - managers and coworkers - claimed about lack of particular competences. Some managers feel stressed and helpless, especially about the gap in different perceptions that they face communicating with colleagues at organizations they work. Concerns and doubts were emphasized evaluating their colleagues' enablement to act and the way they demonstrate such competencies as self-control, self-confidence and empathy.

However, this study revealed that all respondents manifest a lack of mutuality and reciprocity as well as lack of leadership and authority expressed in relevant competences. The findings of this paper made it clear that "The Self" and "The Others" evaluations can essentially differ even in relatively small companies with up to 20 employees. The findings also revealed that differences of competences' evaluations and perceptions originate from different attitudes "About Self" and "The Others". However, since the study used a small sample of respondents, the research results cannot be generalized. It should be pointed out that the research results increase the authors' insights into the root causes of the leadership identity phenomenon so far and they allow the managers of the organizations under study to acknowledge the problem as well as to focus on better understanding. It became evident from the research results that there is a misunderstanding of the leadership identity phenomenon of variety of people identities expressed by their core competences'.

When in-depth interviews are employed, generalizations about the research results are pretty often not able to be made because small samples of the respondents are chosen and random sampling methods are not used. On the other hand, in-depth interviews provide valuable, thus reliable information, specifically when combining other methods of respondents' data collection. It should be noted that the general rule on sample size for interviews is that when the same opinions, beliefs, approaches and arguments are emerging from the interviewees, then a sufficient sample size has been reached. This paper has unveiled manifestations of core competences' that affect everyday communications, relations as well as interaction and reciprocity of people within organizations. Therefore the in-depth interview, as the research tool, could be combined with other qualitative and complex research methods; and could be tested and improved, and the dimensional content could be filled with findings of further empirical research.

\section{References}

Alexander, E. D. 2005. The rule of three: a unified theory of leadership. Business Strategy Review, Vol. Autumn.

Badaracco, J. L. Jr. 2006. Questions of Character: Illuminating the Heart of Leadership through Literature. Harvard Business School Press, Boston, MA.

Basit, N. B. 2010. Conducting research in educational contexts. London: Continuum International Publishing Group.

Bass, B. M., Avolio, B. J. (Eds) 1994. Improving Organizational Effectiveness through Transformational Leadership. Sage Publications, Thousand Oaks, CA.

Binney, G., Wilke, G., Williams, C. 2005. Living Leadership: A Practical Guide for Ordinary Heroes. Pearson Education, Harlow.

Boyatzis, R.E. 1982. The Competent Manager, John Wiley, New York, NY.

Burns, J. M. 2003. Transforming Leadership: A New Pursuit of Happiness. Atlantic Monthly Press, New York, NY.

Covey, S. R. 2004. The 8th Habit: From Effectiveness to Greatness. Simon \& Schuster, New York, NY.

Hegel, G.W.F. 1807. The Phenomenology of the Spirit, Joseph Anton Goebhardt, Bamberg. Oxford University Press, Oxford (trans. by Miller, A.V.).

Cozolino, L. 2006. The Neuroscience of Human Relationships. Attachment and the Developing Social Brain. W.W. Norton \& Co., New York, NY. 
Day, D.V. 2001. Leadership development: a review in context, The Leadership Quarterly 11(4): 581-613. http://dx.doi.org/10.1016/ S1048-9843(00)00061-8

Day, D. V, Harrison, M, Halpin, S. 2008. An Integrative Theory of Leader Development. The Psychology Press, New York, NY.

Dearlove, D., Coomber, S. 2005. A leadership miscellany. Business Strategy Review, Vol. Autumn, p. 53-58.

Elias, N. 1991. The Society of Individuals. Blackwell, Oxford.

Erikson, E.H. 1959. Identity and the Life Cycle, International Universities, New York, NY.

George, B., Sims, P. 2007. True North. Discover Your Authentic Leadership. Jossey-Bass, San Francisco, CA.

Goffee, R., Jones, G. 2006. Why Should Anyone Be Led by You? What It takes to Be an Authentic Leader. Harvard Business School Press, Boston, MA.

Hautala, T. M. 2006. The relationship between personality and transformational leadership, Journal of Management Development 25(8): 777-794. https://doi.org/10.1108/02621710610684259

Higgins, E. T. 1987. Self-discrepancy: a theory relating self and affect, Psychological Review 94(3): 319-340.

Howard, A., Bray, D.W. 1988. Managerial Lives in Transition: Advancing Age and Challenging Times. Guilford Press, New York, NY.

Jinot, B. L. 2018. The Causes of a Lack of Discipline among Secondary School Learners in Mauritius, Mediterranean Journal of Social Sciences https://doi.org/10.2478/mjss-2018-0003

Jung, D. I.; Avolio, B. J. 1999. Effects of leadership style and followers' cultural orientation on performance in group and individual task conditions, Academy of Management Journal 42(2): 208-218. https://doi.org/10.2307/257093

Kark, R., van Dijk, D. 2007. Motivation to lead, motivation to follow: the role of self-regulatory focus in leadership processes, Academy of Management Review 32(2): 500-528. https://doi.org/10.5465/AMR.2007.24351846

Karp T. 2012. Developing oneself as a leader, Journal of Management Deevlopment 32(1): 127-140.

Karp, T., Helgø I.T., 2009. Leadership as identity construction: the act of leading people in organisations, Journal of Management Development 28(10): 880 - 896. https://doi.org/10.1108/02621710911000659

Kets de Vries, M.F.R. 1994. The leadership mystique. Academy of Management Executive 8(3), 73-89.

Kouzes, J.M., Posner, B.Z. 2002. The Leadership Challenge, 3rd ed., Jossey-Bass, San Francisco, CA.

Kouzes, J.M., Posner, B.Z. 2008. The Leadership Challenge, 4th ed., John Wiley, San Francisco, CA.

Kouzes, J. M., Posner, B. Z. 2013. LPI: Leadership Practices Inventory Self; LPI: Leadership Practices Inventory Observer; LPI: Leadership Practices Inventory Workbook. Bublished by The Leadership Challenge ${ }^{\circledR}$

Lodico, M. G., Spaulding, D. T. \& Voegtle, K. H. 2010. Methods in educational research: From theory to practice. San Francisco, CA: Jossey-Bass.

Marcia, J. E. 1966. Development and validation of ego identity status, Journal of Personality and Social Psychology 3: 551-558. http:// dx.doi.org/10.1037/h0023281

McAdams, D. P., Pals, J. L. 2006. A new big five. Fundamental principles for an integrative science of personality, American Psychologist 61(3): 204-217. http://dx.doi.org/10.1037/0003-066X.61.3.204

Mead, G. H. 1934. Mind, Self, and Society: From the Standpoint of a Social Behaviourist. Chicago University Press, Chicago, IL.

Naushad, M. 2018. A study on the antecedents of entrepreneurial intentions among Saudi students, Entrepreneurship and Sustainability Issues 5(3): 600-617. https://doi.org/10.9770/jesi.2018.5.3(14)

Pearce, C. L., Conger, J. A. 2003. All those years ago: the historical underpinnings of shared leadership, in Pearce, C.L., Conger, J.A. (Eds). Shared Leadership: Reframing the Hows and Whys of Leadership. Sage, Thousand Oaks, CA.

Sarantakos, S. 2013. Social research. London: Palgrave MacMillan.

Scharmer, C. T. 2007. Theory U: Leading from the Future as it Emerges. The Social Technology of Presencing. The Society for Organi- 
JOURNAL OF SECURITY AND SUSTAINABILITY ISSUES

ISSN 2029-7017 print/ISSN 2029-7025 online

zational Learning, Cambridge, MA.

Senge, P. M. 1995. The Fifth Discipline: The Art and Practice of the Learning Organization. Doubleday/Currency, New York, NY.

Shaw, P. 2002. Changing Conversations in Organizations: A Complexity Approach to Change. Routledge, London.

Stacey, R. D. 2003. Strategic Management and Organizational Dynamics: The Challenge of Complexity. Pearson Education, Harlow.

Stryker, S. 1968. Identity salience and role performance, Journal of Marriage and the Family 4: 558-564. http://dx.doi.org/10.2307/349494

Short biographical note about the contributors at the end of the article (name, surname, academic title and scientific degree, duties, research interests):

Danutė DISKIENE் - PhD, Professor at the Department of Management, Faculty of Economics and Business Administration, Vilnius University, Lithuania. She authored and co-authored more than 60 scientific publications and three monographs, participated in national and international scientific conferences and projects. Research interests: management, leadership, cross-cultural management, corporate social responsibility.

Rasa PAULIENE - PhD, Ass. Professor at Faculty of Economics and Business Administration, Vilnius University, Lithuania. She is scientific editor of Lithuanian edition of "The Business Book, Big Ideas Simply Explained”, Copyright @ 2014, Dorling Kindersley Limited, A Penguin Random House Company. She authored and co-authored number of scientific publications, made presentations in national and international scientific conferences and projects in accordance with the research interests: leadership and management development; business management; strategic change management; marketing planning, PR \& marketing management. 